\title{
Research on the Protection and Activation of Traditional Villages Based on the Perspective of Self-Organization Theory-Taking Kegeyi Village as an Example
}

\author{
Xuewei Yu \\ School of Architecture, Southwest Minzu University, Chengdu, China \\ Email: 1515985562@qq.com
}

How to cite this paper: Yu, X.W. (2021) Research on the Protection and Activation of Traditional Villages Based on the Perspective of Self-Organization Theory-Taking Kegeyi Village as an Example. Open Access Library Journal, 8: e7810.

https://doi.org/10.4236/oalib.1107810

Received: July 31, 2021

Accepted: August 20, 2021

Published: August 23, 2021

Copyright $\odot 2021$ by author(s) and Open Access Library Inc.

This work is licensed under the Creative Commons Attribution International License (CC BY 4.0).

http://creativecommons.org/licenses/by/4.0/

\begin{abstract}
Traditional villages are the essence of the traditional Chinese culture and an important foundation for China's development. In recent years, with the acceleration of urbanization and unreasonable development of traditional villages, they disappear. In this case, the protection and development of traditional villages are particularly important. This paper uses self-organization theory and the village as an example. By analyzing the characteristics of "self-organization" within the Kegeyi village system and its current protection problems, from the perspective of self-organization theory, the traditional village protection and activation strategy is proposed.
\end{abstract}

\section{Subject Areas}

Urban Planning and Management in Ethnic Minority Areas

\section{Keywords}

Self-Organizing Theory, Traditional Villages, Protection and Activation, Kegeyi Village

\section{Introduction}

As an important carrier of Chinese cultural inheritance, traditional villages are the gene bank of Chinese culture and the source of wisdom of contemporary urban construction, and its existence is crucial. Since 2012, China has been led by the Ministry of Housing and Urban-Rural Development, and a number of ministries have participated in and selected the protection list of "Chinese Tradi- 
tional Villages". So far, five groups of traditional villages have been identified, totaling 6799. However, as China's urbanization accelerates, traditional villages are facing a great threat. In the Blue Book of Chinese Traditional Villages: Investigation Report on the Protection of Chinese Traditional Villages (2017), it is pointed out that there are unoptimistic problems such as a sharp decline in the number of Chinese traditional villages, serious destruction of villages, lack of intangible heritage, damage and pollution of the village environment. Despite increasing attention to traditional villages in recent years, they are still dying. According to the data released by the third conference in 2017, traditional villages have decreased by nearly 920,000 in the past fifteen years, and are disappearing at a rate of 1.6 a day. Therefore, the protection and activation of traditional villages has become an important task. By introducing self-organization theory, we analyze the self-organization characteristics of traditional villages, and study how to protect and activate the self-organization system. As the fourth batch of traditional villages, Kegeyi Village is also a typical minority village. It also faces the problems existing in current traditional villages. Therefore, this article takes Kegyi Village as the research object.

\section{Self-Organization Theory and the Self-Organization Characteristics of Traditional Villages}

\subsection{The Concept of Self-Organization Theory}

Self-organizing theory is a collection of theories that study self-organizing phenomena and laws, which is a theoretical group. The most widely recognized definition of the term "self-organized" is the statement of Hermann Haken, the founder of synergy theory: "If a system has no specific intervention in the structure of obtaining space, time or function, we say that the system is self-organized." In fact, self-organization theory mainly includes dissipative structure theory, synergism theory, fractal theory, etc. These theories respectively explain the scientific principles of self-organization system production conditions, operation mechanism and internal organization relationship from different perspectives, which form the corresponding thought and methodology. This paper mainly uses the dissipative structure theory in the self-organization theory.

\subsection{The Self-Organization Characteristics of Traditional Villages}

As a self-organizing system, traditional villages have the characteristics of openness, nonlinearity, and imbalance.

First, in terms of openness, traditional villages have frequent exchanges with the outside world, including population migration, the exchange of materials, information circulation and so on.

Second, there is a non-linear relationship among the various elements in the traditional village. The uniqueness of a village does not come from the simple addition of the internal population, economy, culture and other elements, but the result of the interaction between the elements. China is a vast territory and 
has a variety of traditional villages, and the architectural forms of their villages are different. For example, Miao villages are mostly stilted buildings, and Dai villages are mostly bamboo buildings and Hani villages are mostly mushroom rooms. These differences in architectural forms may partly come from the differences in residents' lifestyle. This difference is also the reason for the uniqueness of village features. Therefore, in traditional villages, their internal elements are cross-acting, and the change of a certain element may cause unpredictable changes.

Third, from the perspective of nonbalance, the traditional village as a total system, there are differences between its subsystems, such as village population growth, and the existing housing space and infrastructure construction cannot meet the needs of its population growth, on this basis will produce contradiction, in order to solve the contradiction, the village will spread and begin to evolve. Therefore, village neutrino systems are not balanced, which keeps the system away from equilibrium.

According to the above discussion, traditional villages have open, nonlinear and non-balanced characteristics, so they have the basic characteristics of self-organization.

\section{Self-Organized Characteristics of Kogyi Village}

\subsection{Overview of the Village of Kegeyi}

Danba County is located in the western Sichuan Province. It is located on the west slope of Qionglai Mountain at the east foot of Big Snow Mountain. It is located on the west slope of Qionglai Mountain at the east foot of Big Snow Mountain. It belongs to Minshan Mountain and Qionglai High Mountains. It is located in the transition zone from the first step to the second ladder in China, and is a typical high mountain and canyon landform. "Kegeyi" is translated as happy in Tibetan, so Kegeyi Village means a happy village. It is located in the middle of Zhongshan Township, Danba County, the terrain is relatively flat compared with other villages in Danba County, the cultivated land area in the village is vast, and its basic facilities and economic conditions are more advantages compared to other steep and scattered terrains [1].

In terms of ecological culture, Kegeyi Village clearly reflects the traces and characteristics of the cultural exchanges and integration between Tibetan and Qiang groups. Traditional customs are well preserved and have a strong Jiarong Tibetan cultural heritage. The village is rich in cultural life, and all kinds of folk activities and festival activities go deep into daily life, such as Pear Festival and Jiarong Tibetan Style Festival. Tourists from all over the country can enjoy the unique cultural customs of Kegeyi Village, but also the magical and towering Mount of Melbourne and other scenic spots to deeply experience the essence of collector culture. After the demonstration of many famous Chinese historians and archaeologists, the site of the "East Lady Country" is located in Kegeyi Village, Zhonglu Township. Due to its relatively complete natural ecological features, the long historical and cultural deposits of the Tibetan and Qiang people, 
and the unique Tibetan architectural Diaolou, it is listed in the list of "the fourth batch of traditional villages".

\subsection{Self-Organized Characteristics of Kogyi Village}

As the fourth batch of traditional villages, Kegeyi Village belongs to the bottom-up type. In the process of its development and evolution, it is not affected by the superior planning. The process of site selection is a profound influence of the traditional Chinese culture brought by itself. As a traditional Tibetan village, Kegeyi Village has profound Tibetan cultural deposits and reflects the strong Tibetan customs in the construction and evolution of the village. Therefore, according to the dissipative structure theory, the village has openness, balance and nonlinearity.

- The openness of Kogyi village is mainly reflected in its opening to natural bad and the opening of the social environment. From the beginning of settlement, Kergyi will continue to communicate with material, information and other aspects to introduce negative entropy flow, so as to maintain the orderly and healthy development of the village itself, and the open system is gradually formed under this long-term material communication. Because the village is not isolated, there is a large amount of material and information exchange between each village. Now, as the third batch of "Chinese Ethnic Minority Villages" named by the National Ethnic Affairs Commission, it attaches great importance to tourism construction. During the tourism construction process, the exchange of information and material aspects between tourists and villages also increases its openness. It is worth noting that the openness of villages is relative, there are no completely open villages, and its openness is boundary.

- The non-balance of Kogeyi Village is mainly reflected in the non-balance between the subsystems inside the village system, and the differences between the subsystems inside the village. For example, Kogyi village is located in Garz Prefecture, due to the economic differences between it and the town may bring population flow, there are also differences in geographical conditions in the village, so the uneven distribution of the population will produce traffic flow within the village. This "potential difference" is the main factor in the system away from balance.

In fact, the village morphological system is a typical complex nonlinear kinetic system, with universal nonlinear interactions in the various elements or subsystems, and the functional relations between them are also mostly nonlinear [2]. In Kogeyi Village, a single factor is not affected by only one factor. The comprehensive influence of the multiple factors may lead to a "moving the whole body" chain reaction, which may be positive feedback to its growth or negative feedback to its inhibition.

\section{Current Status of Kegeyi Village}

Kegeyi Village is an important tourism demonstration village in Danba County, 
driving the ecological tourism industry of surrounding villages. In 2007, Kegeyi Village was named the most beautiful landscape village in China by the country.

\subsection{Natural Ecology}

The forest reclamation rate of Kegeyi Village is $37.5 \%$, and the natural grassland area accounts for about $44 \%$ of the whole village area. In recent years, the Party committee and government have implemented the natural grassland vegetation restoration and construction and grassland ecological construction projects, and have achieved good results. As there is no industrial industry, the village has no pollution of water and soil. Kegeyi Village is rich in ecological resources, with flower resources, medicinal materials and fungus resources. The ecological environment preservation in the village is relatively complete, so its tourism development value is huge.

\subsection{Cultural Customs and Customs}

"East female" is the sixth century $\mathrm{AD}$, is an important civilization in Western Sichuan and the whole Tibetan history, its existence and development is for the study of Tibetan history is particularly important, and as the "east female country" village still retains distinct female cultural characteristics, such as the middle township continued "top", the township "rob", the "wall" is the ancient female heritage. Therefore, its research and protection is of great value.

As "the most beautiful landscape village in China", "tourism demonstration village" and "the fourth batch of traditional villages", Jiegeyi Village has attached more importance to it. In the "Danba County Tourism Development Plan", it is positioned as "the cultural sightseeing experience and the leisure vacation of Ancient Diaolou Village”.

\subsection{Traditional Architecture}

In terms of traditional architecture, there are about 600 traditional Tibetan dwellings in Zhongshan Township and 88 blockhouses, with rich types and different sizes. Among them, Kangbo ancient Diaolou located in Kegeyi Village is the most complete and only one that can climb on the top of the house. This Diaolou is about 30 meters, which is a typical blockhouse building in Kegeyi Village. As a typical building in Kegeyi Village, the Diaolou can be traced back to the Qin and Han Dynasties, with a history of more than 2000 years. The main materials are mainly stone and soil of natural building materials. The walls are built from inside to outside, which is called "backhand wall". So far, the academic circle has their own views on the role of ancient blockhouses, but what is not believe is that it has high historical, artistic and scientific value from all aspects of history, and architectural skills.

As shown in Table 1, there are three types of village blockhouses, four corner box, five corner box, octagonal blockhouse, the four corner blockhouse is the oldest and most common of all planar types. Its plane is in a "turn back" shape. The 
Table 1. Diaolou type (self-drawn by the author).

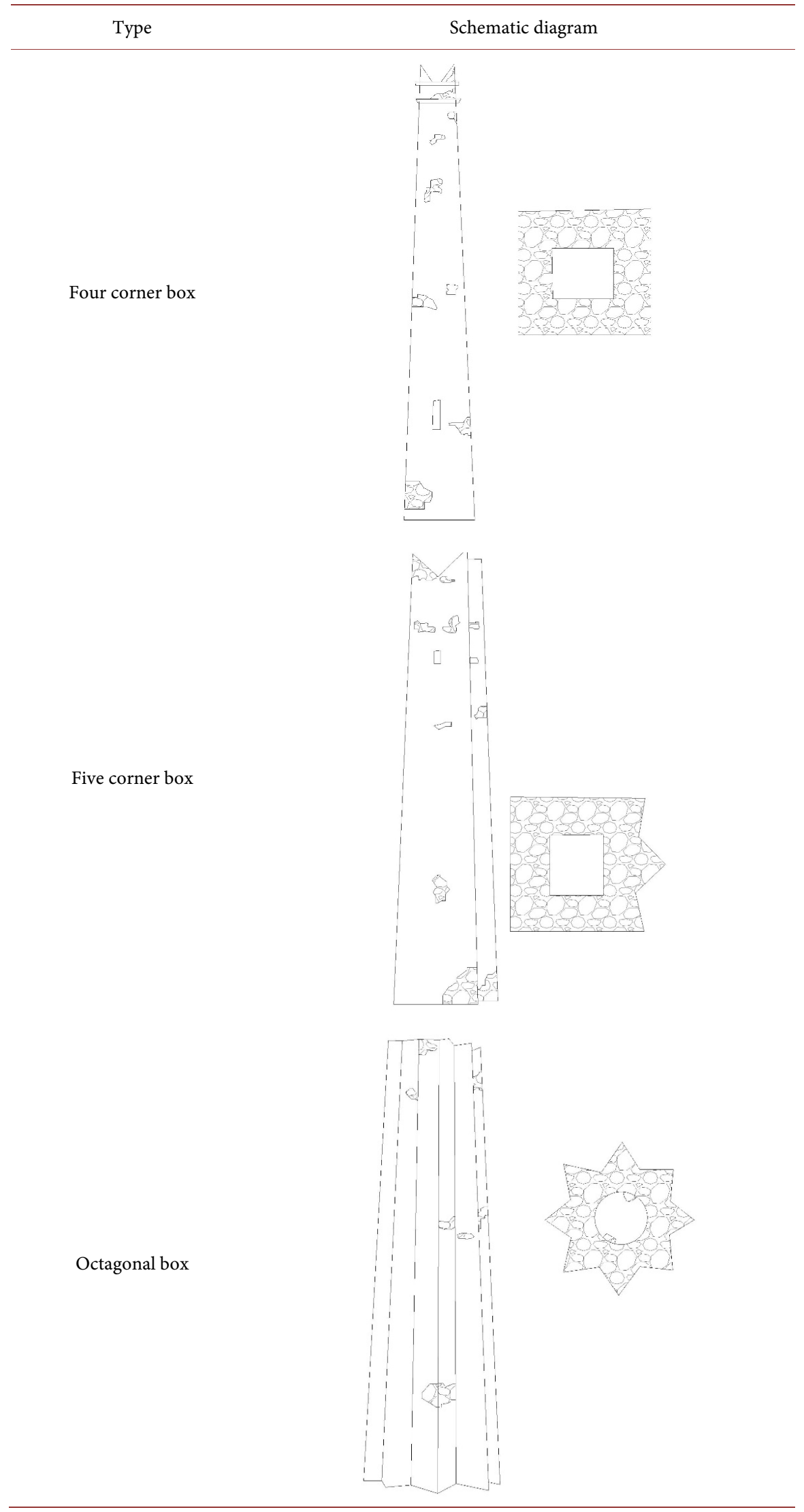


facade is gradually drawn inward upwards from the bottom, a ladder column. The length of the bottom of the four-corner blockhouse is generally $5-8 \mathrm{~m}$, the thickness of the lower part is $1.5-2 \mathrm{~m}$, and the thickness of the top wall is 0.5 $0.6 \mathrm{~m}$, the height of ancient blockhouses is between $25-35 \mathrm{~m}$, and the height of some ancient blockhouses can reach $40 \mathrm{~m}$. The corner blockhouse was developed on the basis of the four corner blockhouse. The difference from the four corner blockhouse is that it mainly adds a corner to the wall with the weaker foundation bearing capacity to increase the contact surface with the foundation, reduce the foundation pressure, and increase the stability of the wall. Its height is between $20-35 \mathrm{~m}$. Octagonal blockhouse has an octagonal star shape on the outside and a perfect circular space in the middle.

In the western part of ancient Shu, the stone architectural art with "fortified dwellings" as the main function was once all over the mountains and canyons. With the formation and expansion of the Tibetan village settlement, in order to fight the tribal invasion and ethnic disputes, the ancient blockhouses were isolated from the blockhouse dwellings and developed into a magnificent and tall ancient blockhouse. Around the 17th century was the most prosperous period, with high blockhouses, known as the "country of thousands of blockhouses" and the "Great Wall of Southwest China". Most of them have disappeared from the ground due to natural and man-made disasters such as war and earthquakes. At the same time, with the development of The Times, the integration, communication and social progress among the nationalities, and the defense function of the ancient blockhouses is degraded. The existing ancient blockhouses are only used as the physical witness of the traditional Tibetan ethnic architectural culture, which is very precious. But due to the passage of time and the weak sense of protection, the number of ancient blockhouses is increasingly scarce.

\section{Problems in the Village of Kegyi}

There are still some problems in protecting the village.

\subsection{Insufficient Understanding of Village Scarcity and Insufficient Protection}

First, local governments are not strong enough to protect traditional villages. Kergyi Village is located in Garze Tibetan Autonomous Prefecture, and the Tibetan area is relatively remote, so the economic situation is relatively backward, so its local government economic capacity is limited, while the protection of traditional villages requires continuous human, material resources and financial input. Meanwhile, although Kergyi Village is listed as the fourth batch of traditional villages, its protection importance is not at the forefront of the local governments with urban construction and economic construction.

\subsection{The Disorder of Village Planning Leads to “Autonomy Destruction"}

In fact, due to the extent of land policy imperfection make the village has a cer- 
tain degree of "self-built damage", some places will exist "old house foundation, new foundation not batch" policy, in the village, there is division in order to apply for homestead, the village more than one hundred homestead, but in fact, only more than ten families, through division make more, approval more homestead, and this homestead is actually outsourced to tourism chain operators. And these operators may cause the "self-built damage" of the local buildings in the village [3].

\subsection{Village Infrastructure Is Backward}

Kegeyi Village because the development of tourism brings certain economic income, but the village road, drainage, electricity and other infrastructure construction need a lot of money, and the investment belongs to the village public utilities, so if the village organization cohesion is insufficient, infrastructure will be difficult to improve, at the same time, although the villagers' income has a certain increase, but still cannot afford the complete infrastructure construction investment. According to the actual situation, the road to other villages showed signs of landslide in 2016; the road has not been cleared until 2019 , and its diversion was not implemented. Its tourism development has also been affected.

\subsection{Lack of Protection Funds and Talent Shortage}

First, compared with the urban cultural heritage, the investment in remote traditional villages is relatively small, which is basically "debt", which leads to the lack of funds for traditional village buildings and no protection and repair. Kegeyi Village also has the above phenomenon to a certain extent. Although the protection of traditional villages has been gradually valued in recent years, it is still a drop in the bucket. Therefore, due to the lack of funds, only the typical buildings with relatively high value are protected in the villages, and the residential houses lack effective protection.

Secondly, due to the long-term downturn in the local construction market in traditional villages, many folk craftsmen have changed careers, and the handicraft skill continues to be weak to a certain extent [4]. For example, the lack of folk craftsmen with ancient blockhouse buildings and repair skills, leads to difficulties in the restoration of ancient blockhouses, which seriously restricts the normal development of the protection of village construction.

\section{The Strategy of Self-Organization Protection and Activation of Kogyi Village}

The protection and activation of Kegeyi Village should ensure the overall spatial pattern of its village and the integrity of architecture and folk customs. Its activation development should be carried out based on the main living standard of the villagers of Kegeyi Village. It should not only protect and activate the village, but also improve the living standard of the villagers. 


\subsection{Carry Forward the Traditional Village Culture and Improve the Awareness of Scarcity}

Through the development of some traditional ritual activities within Kegeyi Village, the historical development of the village is activated, so that the villagers' sense of belonging and common consciousness are stronger [5]. Publicize local culture through featured performances, strengthen understanding of it and further deepen awareness of its scarcity.

\subsection{Orderly Planning, Integrating Space and Functions}

Try to maintain repair rather than construction, reduce modern artificial buildings, and maintain the original appearance of Kegeyi Village. For the outsourced homestead, it can be required to renovate the houses on the homestead according to the overall style control, so as to meet the needs of its tourism operation [6].

\subsection{On the Basis of Respecting the Status Quo, Improve the Functions}

Kegeyi Village relatively retains its original ecological style, on this basis, through the intervention of external forces, such as lack of funds can apply for special financial support, and declare related support projects, can attract private capital to participate in the protection and utilization of traditional villages, to improve the village infrastructure, repair internal road system, add relevant medical security equipment, develop characteristic leisure and entertainment places, in the respect of the original pattern, integration of space and function, village public service facilities and functional zoning [7].

\subsection{Multiple Introduction of Funds, the Increase of Village Talent Training Projects}

From the perspective of self-organization, to achieve the sustainable development of the village, it is best to cultivate the growth ability within the village. In this way, the villagers can become the main participants and beneficiaries by taking the local people as the village development theme [8]. Through the introduction of external financial support, such as private capital, relevant project application funds, the relevant talent training fund is set up in the village, so that the local residents in the village can automatically learn relevant skills and give back to the village.

\section{Conclusion}

Nowadays, in the context of the urbanization process, the communication and coordination with the residents to meet the needs of the local residents can better promote the protection and activation of the traditional villages. In this process, the spontaneous evolution generated through the coordination between village internal systems is actually more effective, and the protection and activa- 
tion of traditional villages should be carried out according to local conditions on the basis of respect for non-equilibrium nonlinearity.

\section{Conflicts of Interest}

The author declares no conflicts of interest.

\section{References}

[1] Committee of Danba County, Sichuan Province, CPPCC (1992) Selection of Danba Literature and History Data. Sichuan Ethnic Publishing House, Chengdu.

[2] Wang, R. and Chen, C. (2016) Settlement Protection and Renewal of Traditional Ancient Towns in Foshan Based on Self-Organization Theory: A Case Study of Xianshi Town in Xantan District, Zigong City. Civil and Environmental Engineering, No. S1, 159-165.

[3] Chen, Z. and Zhou, H. (2012) Research on Traditional Village Renewal and New Residence Construction Based on Self-Organization Theory. Journal of Architecture, No. 4, 109-114.

[4] Guo, R. (2013) Study on Contemporary Renewal Model of Traditional Village Based on Self-Organization Theory. Huazhong University of Science and Technology, Wuhan.

[5] Shen, W. (2001) Self-Organization Theory and Dissipative Structure Theory and Their Geo-Applications. Geochemistry, No. 3, 1-7.

[6] Su, G. (1986) Dissipative Structure Theory. Introduction to Theory, No. 5, 46-48.

[7] Jiang, M. (2015) Study on the Guidance and Control of Contemporary Village Public Space from the Perspective of Self-Organization Theory. Hunan University, Changsha.

[8] Fan, H. (2014) An Empirical Study on Traditional Village Renewal Model Based on Self-Organization Theory. Journal of Chang'an University (Social Science Edition), No. 16, 132-135. 